\title{
Leaching behavior of selected trace elements in coal fly ash samples from Yenikoy coal-fired power plants
}

\author{
Gul Akar ${ }^{\text {a,* }}$, Mehmet Polat ${ }^{\mathrm{b}}$, Greg Galecki ${ }^{\mathrm{c}}$, Uner Ipekoglu ${ }^{\text {a }}$ \\ a Department of Mining Eng., Dokuz Eylul University, Buca, Izmir, Turkey \\ ${ }^{b}$ Department of Chemical Eng., Izmir Institute of Technology, Urla, Izmir, Turkey \\ c Department of Mining and Nuclear Eng., Missouri SET, Rolla, MO, USA
}

\section{A R T I C L E I N F O}

\section{Article history:}

Received 3 May 2012

Received in revised form 18 June 2012

Accepted 22 June 2012

Available online 20 July 2012

\section{Keywords:}

Coal fly ash

Coal-fired power plants

Trace element leaching

\begin{abstract}
A B S T R A C T
Short-term leaching test results of alkaline fly ash from Yenikoy coal-fired power plant were reported in this paper. ASTM D-3987-85 and TCLP-1311 test methods were applied to determine leaching behavior of selected elements namely, $\mathrm{Fe}, \mathrm{Ca}, \mathrm{Cu}, \mathrm{Co}, \mathrm{Cd}, \mathrm{Mn}, \mathrm{Ni}, \mathrm{Pb} \mathrm{Zn}$, and $\mathrm{Cr}$ (VI) at different particle size fractions and test conditions. Chemical, mineralogical and morphological characterizations of ash samples were also performed using chemical, XRD and SEM-EDS analysis methods. The results showed that CaO dominates in the Yenikoy fly ash sample which directly affects the mobility of trace elements by determining the $\mathrm{pH}$ of the leaching medium. Higher mobility values of $\mathrm{Cd}, \mathrm{Co} \mathrm{Cu}, \mathrm{Pb}, \mathrm{Ni}$ and $\mathrm{Zn}$ elements were observed for TCLP-1311 procedure. The concentration of these elements in leachates showed a tendency to increase by decreasing particle size. Overall results suggested that the amount of the selected elements in the final leachates of both tests was lower than the limit values of landfill regulations except $\mathrm{Cr}(\mathrm{VI})$.
\end{abstract}

(c) 2012 Elsevier B.V. All rights reserved.

\section{Introduction}

Coal has always been an important energy source for Turkey. As of today, the lignite based power plants have a production capacity of $20 \%$ of the total energy production [1,2]. Turkish lignites are typically low-grade coals which have very low calorific value and high mineral matter content $[3,4]$. It has been reported in various studies that extreme, high ash yields can reach that range from $23 \%$ to $64 \%[5,6]$, which produce huge quantities of coal fly ash to be disposed. According to the latest numbers, total amount of ash in ponds and landfills have already reached around 100 billion tons in Turkey $[7,8]$. Coal contains significant amount of various trace metals. Most of these trace elements are emitted largely in the fly ash or in association with the surface species of fly ash particles during coal combustion [9-12]. It has been reported that trace element concentrations in fly ash are sometimes 4-10 times higher than their original concentrations in coal samples. The reuse of coal fly ash for different purposes has spurred interest in understanding its environmental impact with focus on metal release [9,13]. Under favoring conditions, a considerable amount of these trace elements can easily be leached out from the surface of fly ash particles by the interaction with water in ponds or landfills $[14,15]$. There are large numbers of papers on prediction of leaching behavior of metals from coal fly ash. The researchers reported that the particle size, initial concentration of trace elements, $\mathrm{pH}$ of solution, leaching time, solid-liquid ratio and other

\footnotetext{
* Corresponding author. Tel.: +90232 3017501 .

E-mail address: gul.akar@deu.edu.tr (G. Akar).
}

properties of the leaching environment are important factors affecting the mobility of the trace elements in aqueous environments [16-20].

Short-term leaching tests are capable of giving critical information in considerably shorter interaction periods and simple means to compare the dissolution behavior of various components [4,21]. Toxicity Characteristic Leaching Procedure (TCLP-1311) and Standard Test Method for Shake Extraction of Solid Waste with Water (ASTM D-3987-85) are commonly used methods for this purpose. These tests are considered as static methods of analysis, and can both be applied for the determination of short-term water solubility characteristics of fly ash samples [22-24].

This study focuses on short-term leaching behavior of $\mathrm{Fe}, \mathrm{Ca}, \mathrm{Cu}$, $\mathrm{Co}, \mathrm{Cd}, \mathrm{Mn}, \mathrm{Ni}, \mathrm{Pb} \mathrm{Zn}$, and $\mathrm{Cr}$ (VI) from Yenikoy fly ash using TCLP-1311 and ASTM-3987-85 tests. The mobility of these elements was investigated on different size fractions of the ash samples. The concentrations in the final leachates were compared with the related limit values of landfill regulations.

\section{Materials and methods}

\subsection{Fly ash sample}

Yenikoy power plant uses 4.8 million tons of low quality lignite and generates 1.2 million tons of ash per year. The samples were collected, in a dry state, from the electrostatic precipitators and stored in airtight plastic containers. 
Particle size distribution of the Yenikoy fly ash was determined using Malvern Mastersize-S laser diffraction particle size analyzer. ELE brand Rigdens Flowmeter EL38-0500 was employed to determine the surface area of Yenikoy fly ash using the procedure described in ASTM C 204-11 [25].

The collected samples were dried at $105{ }^{\circ} \mathrm{C}$ for $24 \mathrm{~h}$ and ground using an agate mill to a particle size less than $100 \mu \mathrm{m}$ for mineralogical and chemical analysis. The crystalline minerals in the sample were identified using RIGAKU-Dmax-2200 PC equipment ( $\mathrm{Cu}-\mathrm{K} \alpha$ radiation, $32 \mathrm{kV}, 22 \mathrm{~mA}$ ). Philips XL-30S FEG type scanning electron microscopy (SEM) system was used to examine morphology of the particles. The chemical composition of the ash samples were determined by Perkin Elmer AAS-2280 atomic absorption spectrometer. Concentration of total dissolved $\mathrm{Cr}(\mathrm{VI})$ was determined using the calorimetric method developed by USGS [26].

\subsection{Batch tests}

Yenikoy fly ash sample was classified into different particle size fractions using appropriate sieves prior to use in the tests. These mono size samples were dried at $105{ }^{\circ} \mathrm{C}$ for $48 \mathrm{~h}$ and cooled down to room temperature in a desiccator to remove hygroscopic moisture. Two different toxicity test procedures were employed in the study. Each test procedure requires the application of special experimental conditions.

- TCLP-1311 test is applied to evaluate potential leachability of the toxic substances from the fly ash samples [22,24,27]. The tests were performed using 20:1 liquid-to-solid ratio, $40 \mathrm{~g}$ of fly ash from every size fractions was taken into acid-cleaned $1000 \mathrm{ml} v$ volume polyurethane bottles and $800 \mathrm{ml}$ of extraction fluid (acetic acid solution) was added as described in US EPA protocol. The bottles were then subjected to horizontal shaking at $30 \mathrm{rpm}$ in an oscillating shaker for $18 \pm 2 \mathrm{~h}$ and $22 \pm 3{ }^{\circ} \mathrm{C}$.

- The water leaching test described in ASTM D 3987-85 is useful to evaluate the leaching potential of a material being exposed to normal precipitation. This method uses the liquid-to-solid ratio of 20:1. $40 \mathrm{~g}$ of fly ash samples was added to $800 \mathrm{ml}$ of deionized water into acid-cleaned $1000 \mathrm{ml}$ polyurethane bottles and agitated continuously at a rate of $29 \mathrm{rpm}$ for $18 \mathrm{~h}$ at room temperature $\left(25^{\circ} \mathrm{C}\right)$.

After agitation on the shaker, the mixture was allowed to settle for 5 min for both methods, and then the aqueous phase separated by decantation. The $\mathrm{pH}$ of the leachates was determined immediately after collection. The leachates were then filtered through a $0.45 \mathrm{~mm}$ filter paper by vacuum filtration system, and acidified with nitric acid to $\mathrm{pH} 2$. The sampling bottles were preserved of volume change and evaporation [23]. Element concentrations in the leachates were determined by using Perkin Elmer 2280 model atomic absorption spectrometer and $\mathrm{Cr}(\mathrm{VI})$ was measured at $540 \mathrm{~nm}$ with an UVvisible spectrophotometer.

\section{Result and discussion}

\subsection{Physical and chemical characterization of fly ash sample}

Particle size is one of the important factors influencing the reaction kinetics in leaching of fly ash. The fine particles, particularly the very fine particles in coal ash play an important role in this process due to their large active surface area [28]. It may also show an effect upon chemical composition such as trace element distribution within the ash $[29,30]$.

As depicted in Fig. 1, about $80 \%$ of the Yenikoy fly ash is under $45 \mu \mathrm{m}$ particle sizes. Volumetric mean particle size and $10 \%$ passing size values of the material were found as $28.41 \mu \mathrm{m}$ and $1.86 \mu \mathrm{m}$ respectively. Results of the physical characterization studies were

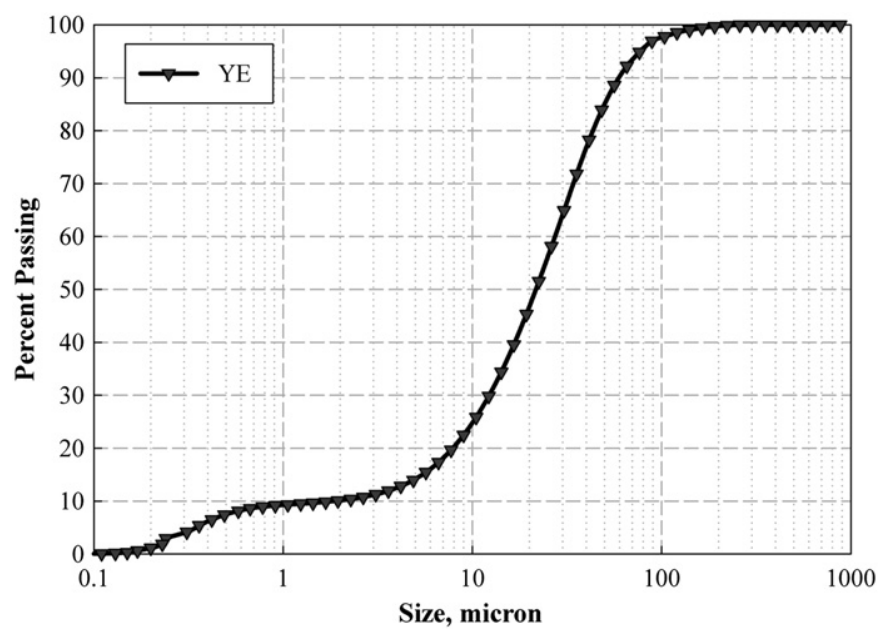

Fig. 1. Size distribution plots of Yenikoy fly ash.

found to be in agreement with the results of the study conducted by Bayat in 1999 [31].

Specific gravity as a function of porosity and surface area of the particles also influence the interactions between fly ash and aqueous solution. As seen from Table 1 , specific gravity and surface area values of the sample were found as $2.86 \mathrm{~g} / \mathrm{cm}^{3}$ and $0.175 \mathrm{~m}^{2} / \mathrm{g}$.

Natural pH value of fly ash is an important property which has a significant effect on mobility of trace elements in aqueous environment. Fly ash-water slurry was prepared by mixing $5 \mathrm{~g}$ of fly ash with $100 \mathrm{ml}$ of deionized water for the determination of the $\mathrm{pH}$ value of the sample. The $\mathrm{pH}$ of slurry had been recorded at $1 \mathrm{~h}$ intervals for a period of $24 \mathrm{~h}$ using WTW brand $\mathrm{pH} /$ Cond. 340i portable water meter and final $\mathrm{pH}$ was found as 13.2. The basic character of ash leachate is generally attributed to the free calcium, soluble metal salts, oxides, hydroxides, and carbonates $[4,32]$.

Chemical analysis of the fly ash sample was performed to determine the composition of material and results are given in Table 2 . $\mathrm{CaO}$ was found as the major component in the ash sample which was mostly originated from calcite in feed coal. As it was stated by Koukouzas et al., total and free $\mathrm{CaO}$ are mostly generated through the thermal disruption of $\mathrm{CaCO}_{3}$ [33]. As seen from Table 2, the sample contains significant amount of silicon, aluminum and iron elements due to the presence of clay minerals in feed coal. Relatively

Table 1

Some physical properties of Yenikoy fly ash.

\begin{tabular}{lllll}
\hline $\mathrm{D}[4,3]$ & $\mathrm{D}(\mathrm{v}, 0.1)$ & Specific gravity $\left(\mathrm{g} / \mathrm{cm}^{3}\right)$ & Specific surface area $\left(\mathrm{m}^{2} / \mathrm{g}\right)$ & $\mathrm{pH}$ \\
\hline 28.41 & 1.86 & 2.86 & 0.175 & 13.2 \\
\hline
\end{tabular}

Table 2

Concentration of major and trace elements in Yenikoy fly ash $[34,35]$.

\begin{tabular}{lclr}
\hline Elements (as oxides) & $(\%)$ & Trace elements & $(\mathrm{mg} / \mathrm{kg})$ \\
\hline $\mathrm{CaO}$ & 38.24 & $\mathrm{Zn}$ & 77.84 \\
$\mathrm{SiO}_{2}$ & 20.79 & $\mathrm{Cd}$ & 14.90 \\
$\mathrm{Al}_{2} \mathrm{O}_{3}$ & 17.26 & $\mathrm{Co}$ & 77.12 \\
$\mathrm{Fe}_{2} \mathrm{O}_{3}$ & 7.17 & $\mathrm{Ni}$ & 73.69 \\
$\mathrm{MgO}_{\mathrm{SO}}$ & 4.66 & $\mathrm{Cu}$ & 72.08 \\
$\mathrm{Na}_{2} \mathrm{O}$ & 12.8 & $\mathrm{~Pb}$ & 149.81 \\
$\mathrm{~K}_{2} \mathrm{O}$ & 2.19 & $\mathrm{Mn}$ & 262.49 \\
$\mathrm{BaO}$ & 1.33 & $\mathrm{Cr}$ & 220.13 \\
\hline
\end{tabular}




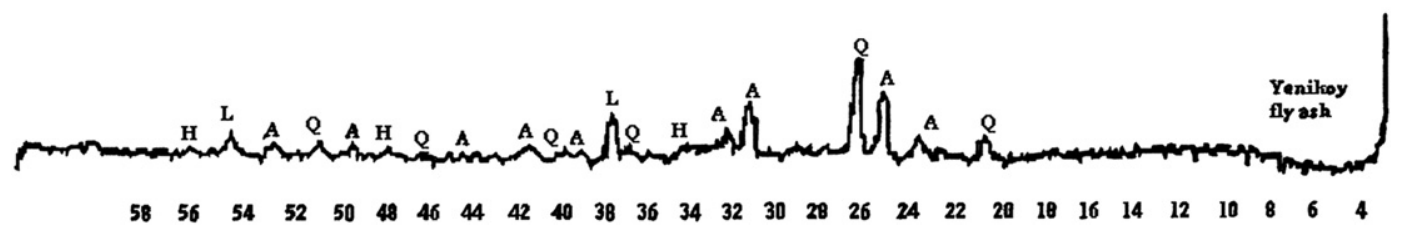

Fig. 2. $\mathrm{XRD}$ analysis results of the ash samples $\left(\mathrm{Q}=\right.$ quartz $\left(\mathrm{SiO}_{2}\right), \mathrm{A}=$ anhydrite $\left(\mathrm{CaSO}_{4}\right), \mathrm{L}=$ lime $(\mathrm{CaO}), \mathrm{H}=$ hematite $\left.\left(\mathrm{Fe} \mathrm{O}_{3}\right)\right)$.
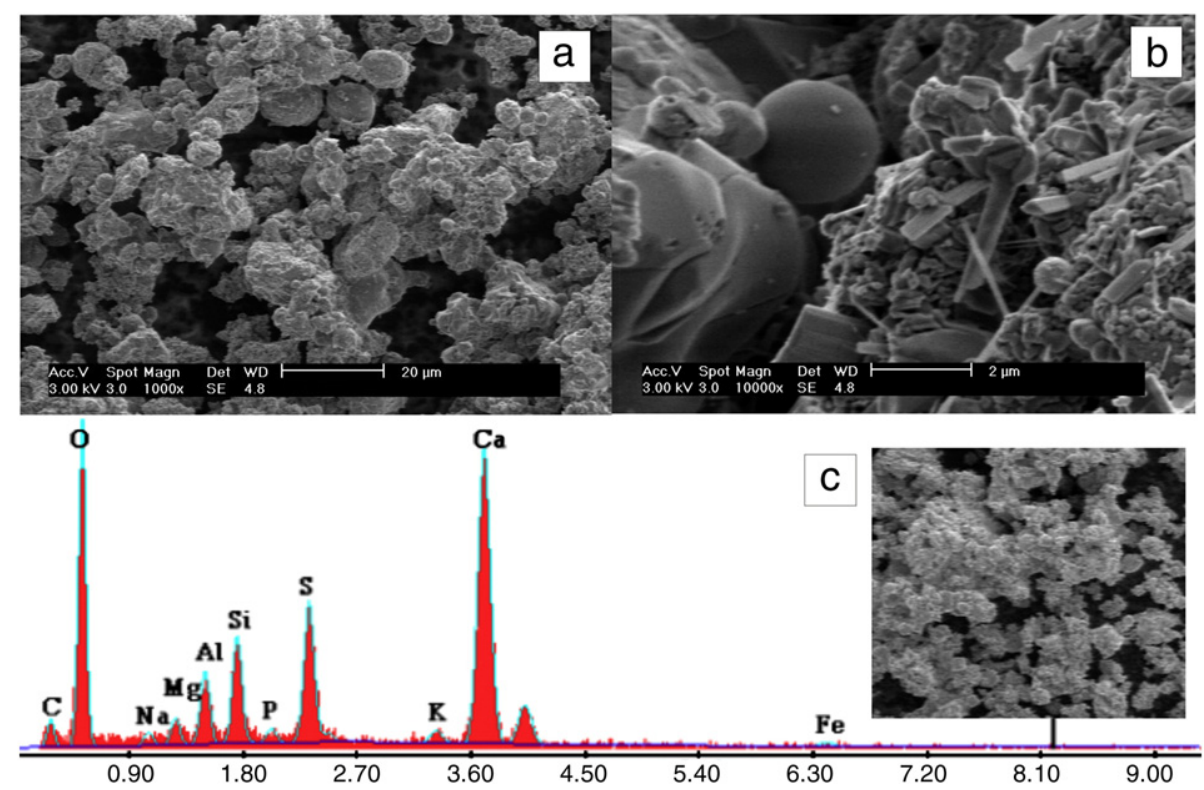

Fig. 3. (a, b) SEM image of general view of Yenikoy fly ash, (b) SEM image of a surface detail, and (c) SEM image and X-ray energy dispersed spectrum in the field.

high concentrations of $\mathrm{Pb}(149.81 \mathrm{mg} / \mathrm{kg}), \mathrm{Cr}(220.13 \mathrm{mg} / \mathrm{kg})$ and $\mathrm{Ni}$ $(73.69 \mathrm{mg} / \mathrm{kg}$ ) were also detected in the fly ash.

\subsection{Mineralogical characterization of Yenikoy fly ash sample}

X-ray diffraction analysis was performed to determine the mineralogical properties of the fly ashes. The analyses were carried out using RIGAKU-Dmax-2200 PC equipment ( $\mathrm{Cu}-\mathrm{K} \alpha$ radiation, $32 \mathrm{kV}$, $22 \mathrm{~mA}$ ) and the results are shown in Fig. 2.

As can be seen from Fig. 2, Yenikoy ash consists of quartz, anhydrite, lime (free and total) and hematite minerals. $\mathrm{CaO}$ and $\mathrm{CaSO}_{4}$ minerals were detected as the major source of calcium in the sample. Quartz was observed as the dominating silicon compound, and iron was identified as in the form of $\mathrm{Fe}_{2} \mathrm{O}_{3}$ mineral. Zhao et al pointed out that calcium oxide is one of the characteristic phases in the combustion products of a high calcium coal [36]. As mentioned by Vamvuka and Kakaras, anhydrite was generally derived from fixing sulfur dioxide with lime and/or dehydration of gypsum in coal [37].

Morphological property of the particles affects the mobility of the trace elements in fly ashes. The particles having relatively high density and nonporous outer surface may resist leaching of heavy metals [4,20]. That's why, SEM analysis was applied to find out morphological properties of the particles using a Philips XL-30S FEG type instrument at different magnifications and results are given in Fig. 3.

As shown in Fig. 3a and b, the sample contains individual particles and agglomerates of particulates in spherical or irregular shape as it was reported by Bayat [31]. Those particles are considered to be generated by the fusion of smaller fragments and incomplete melting process. A number of individual particles were observed in the range of 1 and $10 \mu \mathrm{m}$ and many of them with a diameters less than $2 \mu \mathrm{m}$ (Fig. 3a and b). As can be seen from Fig. 3c, high amount of Ca, $\mathrm{Si}, \mathrm{Al}$ was detected in fly ash.
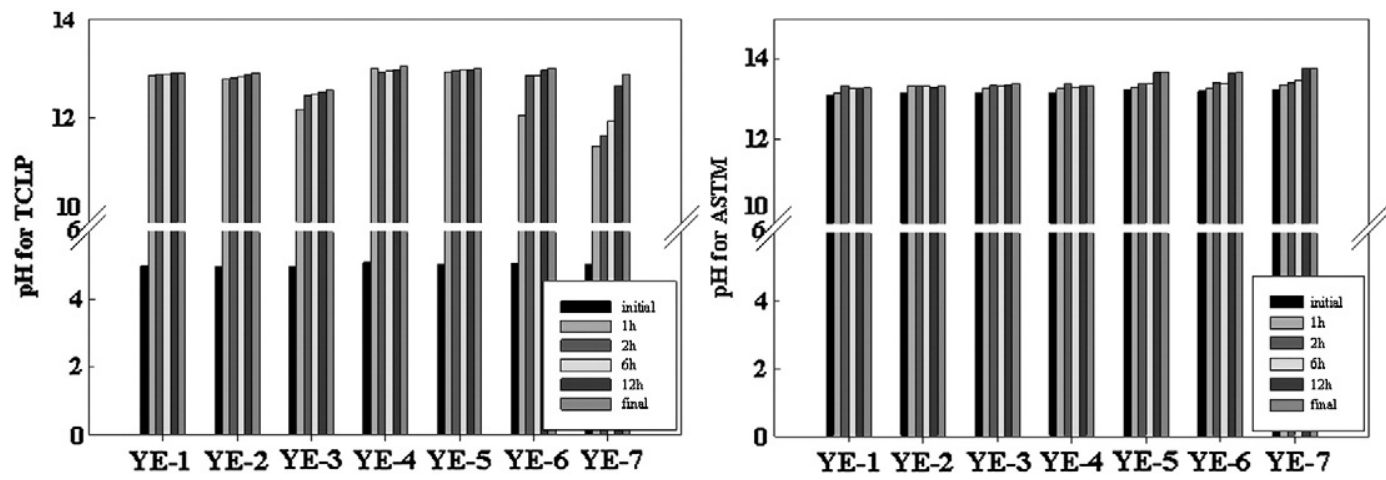

Fig. 4. (a) Variations in the pH value of the solutions during the TCLP tests, and (b) variations in the pH value of the solutions during the ASTM tests. 
Table 3a

The concentration of heavy metals in Yenikoy TCLP leachates $(\mathrm{mg} / \mathrm{kg})$.

\begin{tabular}{|c|c|c|c|c|c|c|c|c|c|c|c|}
\hline \multirow[t]{2}{*}{ Samples } & \multirow{2}{*}{$\begin{array}{l}\text { YE-1 } \\
(+212 \mu \mathrm{m})\end{array}$} & \multirow{2}{*}{$\begin{array}{l}\text { YE-2 } \\
(212-150 \mu \mathrm{m})\end{array}$} & \multirow{2}{*}{$\begin{array}{l}\text { YE-3 } \\
(150-106 \mu \mathrm{m})\end{array}$} & \multirow{2}{*}{$\begin{array}{l}\text { YE-4 } \\
(106-75 \mu \mathrm{m})\end{array}$} & \multirow{2}{*}{$\begin{array}{l}\text { YE-5 } \\
(75-53 \mu \mathrm{m})\end{array}$} & \multirow{2}{*}{$\begin{array}{l}\text { YE-6 } \\
(53-38 \mu \mathrm{m})\end{array}$} & \multirow{2}{*}{$\begin{array}{l}\text { YE-7 } \\
(-38 \mu \mathrm{m})\end{array}$} & \multirow{2}{*}{$\begin{array}{l}\text { YE } \\
\text { (as is) }\end{array}$} & \multicolumn{3}{|c|}{ Waste acceptance criteria, mg/kg } \\
\hline & & & & & & & & & Inert & Nonhazardous & Hazardous \\
\hline $\mathrm{Fe}$ & 4.2 & 3.2 & 4 & 2.8 & 4 & 4.6 & 3.4 & 3.6 & & & \\
\hline $\mathrm{Ca}$ & 67,040 & 55,360 & 58,400 & 48,320 & 78,720 & 85,120 & 74,880 & 72,320 & & & \\
\hline $\mathrm{Zn}$ & 2 & 1.6 & 1.8 & 1.6 & 2 & 2 & 2 & 1.8 & 4 & 50 & 200 \\
\hline $\mathrm{Cd}$ & 2.8 & 2.2 & 2.4 & 2 & 2.8 & 2.8 & 3 & 2.8 & 0.04 & 1 & 5 \\
\hline Co & 3.2 & 2.8 & 2.2 & 2 & 2 & 2.6 & 2.4 & 2.4 & & & \\
\hline $\mathrm{Ni}$ & 4 & 3.6 & 4.8 & 4 & 3.4 & 3.4 & 5.6 & 4.6 & 0.4 & 10 & 40 \\
\hline $\mathrm{Cu}$ & 2.8 & 2.6 & 2.6 & 2.6 & 3.2 & 3.2 & 3.4 & 3.4 & 2 & 50 & 100 \\
\hline $\mathrm{Pb}$ & 11 & 10 & 11 & 10.4 & 14.2 & 15 & 14.4 & 14.0 & 0.5 & 10 & 50 \\
\hline $\mathrm{Mn}$ & 1.8 & 1.6 & 1.6 & 1.4 & 1.6 & 1.6 & 1.8 & 1.8 & & & \\
\hline $\mathrm{Cr} 6$ & 2.01 & 2.54 & 3.56 & 3.65 & 4.012 & 10.28 & 13.4 & 9.6 & 0.5 & 10 & 70 \\
\hline
\end{tabular}

\subsection{Results of the toxicity test procedures}

In this part of the study, two standard leaching tests (TCLP 1311 and ASTM3987-85) were used to determine the mobility of trace elements in Yenikoy fly ash. TCLP 1311 test simulates the solubility of different elements when fly ash exposed to a weak acid rain water environment. ASTM 3987-85 test characterizes water leaching behavior of fly ash at low concentrations of solid material.

Fly ash samples were classified into different particle size fractions,

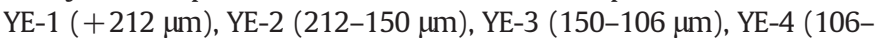
$75 \mu \mathrm{m}), \mathrm{YE}-5$ ( $75-53 \mu \mathrm{m}), \mathrm{YE}-6(53-38 \mu \mathrm{m}), \mathrm{YE}-7$ ( $-38 \mu \mathrm{m}), \mathrm{YE}$ (as is) and subjected to leaching tests to determine the fractionation and mobility of trace elements in aqueous environments.

As it was stated by Koukouzas [33], solubility of some trace elements may significantly change depending on the $\mathrm{pH}$ of the solution. For this reason, $\mathrm{pH}$ variations should be monitored during toxicity test procedures, and the final $\mathrm{pH}$ values should be taken into consideration in the evaluation of the test results. The high concentrations of calcium may cause secondary precipitation reactions and limit the solubility of some metals [38,39].

Variations in the $\mathrm{pH}$ values were closely monitored and recorded using the same conditions with toxicity test procedures prior to the tests. It is important to note that the $\mathrm{pH}$ of the solutions was adjusted to 5 to provide the initial condition for TCLP test method. However, the solution $\mathrm{pH}$ was measured over 12 after $1 \mathrm{~h}$ (Fig. 4).

For all fractions of fly ash samples, initial $\mathrm{pH}$ values of leachates were observed in the range of 12 to 13 after water addition step of ASTM test methods. As seen from Fig. $4 a$ and $b$, the final $\mathrm{pH}$ values of the leachates are varying between 12 and 13.5 for different fractions of fly ash sample. At the end of the TCLP test, slightly lower $\mathrm{pH}$ values were measured compared to ASTM method.

Zandi et al. and Izquierdo et al. suggested that the surface of a fly ash particle is only microns in thickness and can contain leachable heavy metals due to condensation on to the surface. According to previous studies, some elements such as $\mathrm{Ca}, \mathrm{Cr}$ and $\mathrm{Mg}$ are reported to the surface of the fly ash particles, while $\mathrm{Al}, \mathrm{Si}, \mathrm{K}, \mathrm{Pb}$ and many other trace elements are distributed throughout the particle $[40,41]$. Most of the cationic elements including $\mathrm{Mg}, \mathrm{Cu}, \mathrm{Mn}$ and $\mathrm{Ni}$, show lower leaching rates due to their chemical behavior in solution below $\mathrm{pH} 10$. Strong alkaline conditions over $\mathrm{pH}>10$ may induce their release due to desorption/dissolution reactions. The leachability of heavy metals such as $\mathrm{Zn}$ and $\mathrm{Cd}$ is minimal around $\mathrm{pH}$ 7. The solubility of these elements tends to increase at $\mathrm{pH}$ levels above and below 7. Solubility of $\mathrm{Cr}$ increases with increasing $\mathrm{pH}$ for $\mathrm{pH}$ levels over 7 and decreases in strong basic conditions $(\mathrm{pH}>11)$ [38-40].

It can be said that very similar results with the previous studies about Yenikoy fly ash were obtained for ASTM method. However, different trace element concentrations were detected in the leachates of TCLP tests compared to the same studies $[17,33]$. This is most probably due to the difference between the presented final $\mathrm{pH}$ values in this paper and the final $\mathrm{pH}$ values reported by the researchers $[17,33]$, which are 13 and 5 respectively.

The results of the leaching tests were in Tables $3 a$ and $3 b$ along with the limit values of waste acceptance for land filling stated in the Annex 2 of the 2003/33/CE Council Decision (based on 1999/31/ EC Directive) [9]. As seen from Tables 3a, 3b, for all the fractions, most of trace elements gave higher leaching rates for TCLP 1311 compared to ASTM method due to its slightly harsher conditions. It is also possible to say that higher trace element concentrations $(\mathrm{Cd}, \mathrm{Pb}, \mathrm{Cu})$ were observed in the leachates of finer particle size fractions for TCLP 1311 method [42]. Higher Cr (VI) concentrations were detected in the leachates of the finest particle size fraction for both test methods. It is worth pointing out that concentration of $\mathrm{Cd}^{+2}, \mathrm{Ni}^{+2}$, $\mathrm{Pb}^{+2}$ and $\mathrm{Cr}(\mathrm{VI})$ showed higher values than inert limit for waste acceptance criteria for TCLP 1311 method.

The relationship between the ash particle size and percentage of trace elements in leachates is given in Fig. 5. It becomes evident from Fig. 5 that the highest releases for the studied fly ash samples correspond to $\mathrm{Ca}$. Ca concentration in the leachates were found to be higher concentration in the particle size fraction of finer than $75 \mu \mathrm{m}$ (YE-5, YE-6, YE-7, Fig. 5). As seen from Fig. 5, the percentages of other selected elements in solution are very low compared to $\mathrm{Ca}$

Table 3b

The concentration of heavy metals in Yenikoy ASTM leachates $(\mathrm{mg} / \mathrm{kg})$.

\begin{tabular}{|c|c|c|c|c|c|c|c|c|c|c|c|}
\hline \multirow[t]{2}{*}{ Samples } & \multirow{2}{*}{$\begin{array}{l}\text { YE-1 } \\
(+212 \mu \mathrm{m})\end{array}$} & \multirow{2}{*}{$\begin{array}{l}\text { YE-2 } \\
(212-150 \mu \mathrm{m})\end{array}$} & \multirow{2}{*}{$\begin{array}{l}\text { YE-3 } \\
(150-106 \mu \mathrm{m})\end{array}$} & \multirow{2}{*}{$\begin{array}{l}\text { YE-4 } \\
(106-75 \mu \mathrm{m})\end{array}$} & \multirow{2}{*}{$\begin{array}{l}\text { YE-5 } \\
(75-53 \mu \mathrm{m})\end{array}$} & \multirow{2}{*}{$\begin{array}{l}\text { YE-6 } \\
(53-38 \mu \mathrm{m})\end{array}$} & \multirow{2}{*}{$\begin{array}{l}\text { YE-7 } \\
(-38 \mu \mathrm{m})\end{array}$} & \multirow{2}{*}{$\begin{array}{l}\text { YE } \\
\text { (as is) }\end{array}$} & \multicolumn{3}{|c|}{ Waste acceptance criteria, mg/kg } \\
\hline & & & & & & & & & Inert & Nonhazardous & Hazardous \\
\hline $\mathrm{Fe}$ & 2.0 & 2.6 & 3.0 & 2.8 & 4.6 & 4.4 & 3.0 & 3.2 & & & \\
\hline $\mathrm{Ca}$ & 23,200 & 28,160 & 37,440 & 31,040 & 44,800 & 41,600 & 43,840 & 40,160 & & & \\
\hline $\mathrm{Zn}$ & 1.0 & 1.4 & 1.2 & 1.2 & 1.4 & 1.8 & 1.2 & 1.4 & 4 & 50 & 200 \\
\hline $\mathrm{Cd}$ & 1.2 & 1.6 & 1.8 & 1.6 & 1.8 & 1.6 & 1.4 & 1.4 & 0.04 & 1 & 5 \\
\hline Co & 1.4 & 1.2 & 1.4 & 1.4 & 1.4 & 1.4 & 1.2 & 1.2 & & & \\
\hline $\mathrm{Ni}$ & 2.0 & 2.2 & 2.8 & 2.6 & 2.2 & 2.6 & 3.0 & 2.6 & 0.4 & 10 & 40 \\
\hline $\mathrm{Cu}$ & 2.0 & 2.0 & 2.0 & 2.0 & 2.2 & 2.4 & 2.4 & 2.4 & 2 & 50 & 100 \\
\hline $\mathrm{Pb}$ & 6.0 & 6.2 & 5.8 & 5.8 & 7.0 & 6.8 & 7.0 & 6.6 & 0.5 & 10 & 50 \\
\hline Mn & 1.0 & 1.0 & 1.0 & 1.0 & 1.0 & 1.0 & 1.1 & 1.0 & & & \\
\hline $\mathrm{Cr}(\mathrm{VI})$ & 3.02 & 3.69 & 4.26 & 5.32 & 5.54 & 18.85 & 20.46 & 14.8 & 0.5 & 10 & 70 \\
\hline
\end{tabular}



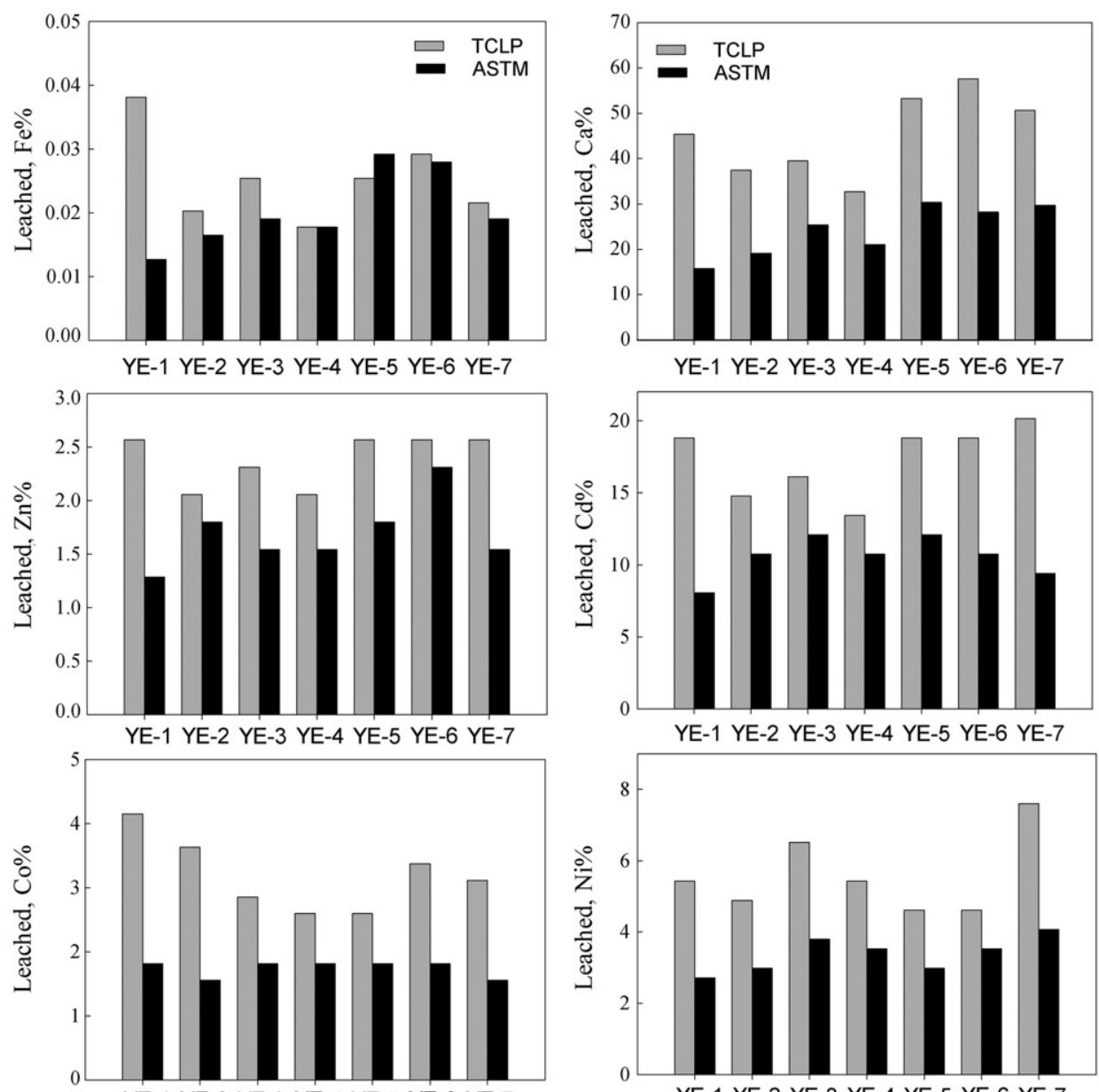

YE-1 YE-2 YE-3 YE-4 YE-5 YE-6 YE-7
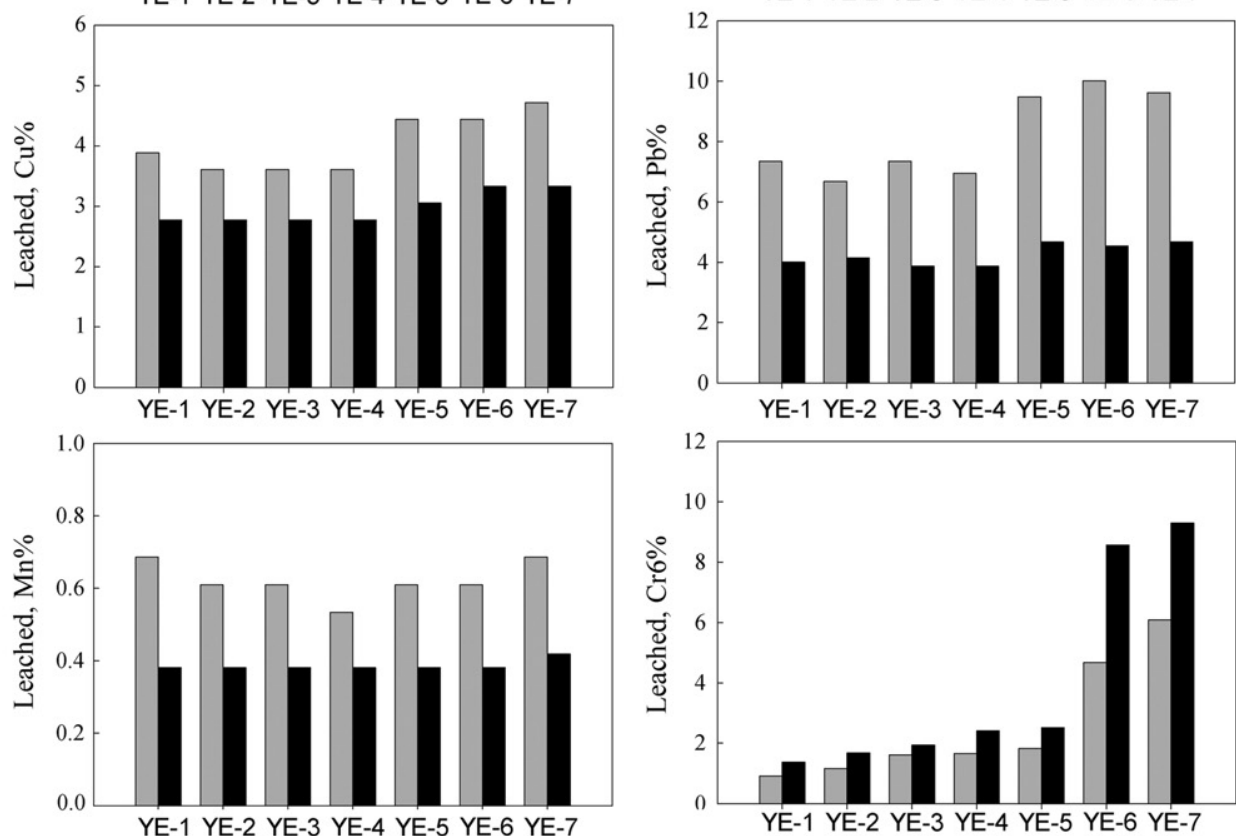

YE-1 $(+212 \mu \mathrm{m})$, YE-2 $(212-150 \mu \mathrm{m})$, YE-3 $(150-106 \mu \mathrm{m})$, YE-4 $(106-75 \mu \mathrm{m})$, YE-5 $(75-53 \mu \mathrm{m})$, YE-6 $(53-38 \mu \mathrm{m})$, YE-7 (-38 $\mu \mathrm{m})$

Fig 5. Results of TCLP 1311 and ASTM 3987-85.

which indicates that these elements are either bound in the glassy phases or there are no favorable conditions for leaching.

According to particle size analysis, the Yenikoy ash contains high amount of fines which makes the material to show very similar leaching characteristics with these fine fractions (Tables 3a and 3b). As can be seen from Fig. 6, higher element concentrations were detected in the leachates of TCLP 1311 method except for $\mathrm{Cr}(\mathrm{VI})$. The highest solubility values were observed for $\mathrm{Ca}, \mathrm{Pb}, \mathrm{Cr}(\mathrm{VI})$ respectively. Compared with 


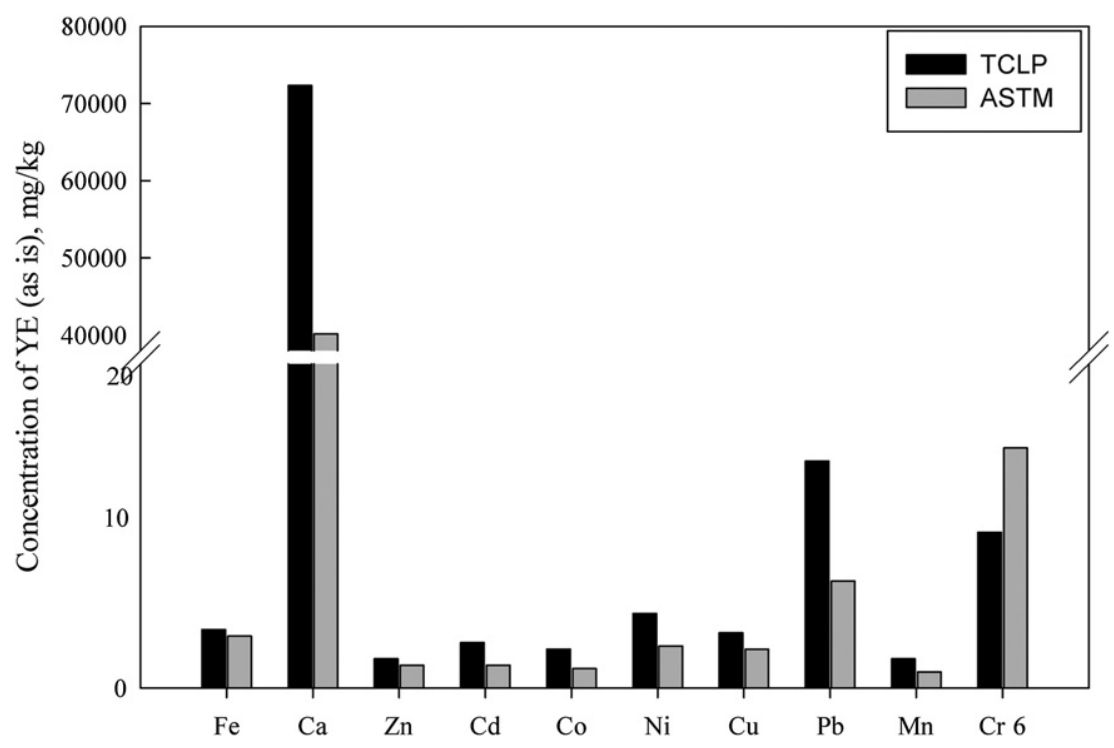

Fig. 6. The concentration of heavy metals in YE (as is) TCLP and ASTM leachates (mg/kg).

the regulatory requirements for waste acceptance, $\mathrm{Zn}$ yielded very low concentrations in both test methods and should therefore not be regarded as a matter of concern. The elements of $\mathrm{Ni}$ and $\mathrm{Cu}$ gave lower concentrations than the limit value of non-hazardous materials for both test methods, whereas the concentration of $\mathrm{Cr}(\mathrm{VI})$ was slightly higher for ASTM 3987-85 method. Based on the presented results, it can be concluded that releases of the selected trace elements were detected as lower than the hazardous material limit values of waste acceptance for land filling stated in the Annex 2 of the 2003/33/CE Council Decision (based on 1999/31/EC Directive).

\section{Conclusions}

TCLP 1311 and ASTM 3987-85 toxicity test methods were applied to find out the mobility of some selected trace elements. According to the results, Ca was found as the most mobile element while Mn and Fe had the lowest mobility. The dissolution of selected trace elements was observed as higher for the particles below $38 \mu \mathrm{m}$ size. For the leaching tests of original fly ash material, the highest solubility values were observed for $\mathrm{Ca}, \mathrm{Pb}$, and $\mathrm{Cr}$ (VI) respectively. The results suggested that releases of these trace elements were all lower than the allowed limits for solid wastes imposed by the EC Directive. The concentrations of $\mathrm{Cr}(\mathrm{VI})$ in some fractions exceeded the non-hazardous material limit value, that's why it should carefully be monitored. The results presented in this paper are useful and enlightening for understanding the mobility of some heavy metals from fly ash samples of Yenikoy power plants. However, long-term leaching tests are still required to obtain further information about leaching behavior of these selected trace elements for making a more adequate assessment.

\section{Acknowledgments}

The authors are grateful to the management of Yenikoy power plant for their collaboration during the sampling process.

\section{References}

[1] EUAS, Annual report, Turkey, http://www.enerji.gov.tr/yayinlar_raporlar/Sektor_ Raporu_EUAS 2009.pdf2010.

[2] BP, Statistical Review of World Energy, www.bp.com/statisticalreviewJune, 2011

[3] A. Baba, A. Kaya, Y. Birsoy, The effect of Yatagan thermal power plant (Mugla-Turkey) on the quality of surface and ground waters, Water Air Soil Poll. 149 (2003) 93-111.

[4] H. Haykiri-Acma, S. Yaman, N. Ozbek, S. Kucukbayrak, Mobilization of some trace elements from ashes of Turkish lignites in rain water, Fuel 90 (2011) 3447-3455.
[5] A.I. Karayigit, R.A. Gayerb, X. Querol, T. Onacak, Contents of major and trace elements in feed coals from Turkish coal-fired power plants, International Journal of Coal Geology 44 (2000) 169-184.

[6] S. Esenlik, A.I. Karayigit, Y. Bulut, X. Querol, A. Alastuey, O. Font, Element behavior during combustion in coal-fired Orhaneli power plant, Bursa-Turkey, Geologica Acta 4 (2006) 439-449.

[7] G. Akar, Determination of heavy metal contamination resulting from coal ash disposal areas, M.Sc. Thesis, Dokuz Eylul University, 2001.

[8] G. Akar, V. Arslan, U. Ipekoglu, U. Tekir, Acid-base production potentials of ash-bearing samples from Soma and Yatagan power plants in Turkey, In: XVI Int. Coal Prep. Congress, 2010, pp. 937-946.

[9] G. Jegadeesan, S.R. Al-Abed, P. Pinto, Influence of trace metal distribution on its leachability from coal fly ash, Fuel 87 (2008) 1887-1893.

[10] S.K. Choi, S. Lee, Y.K. Song, H.S. Moon, Leaching characteristics of selected Korean fly ashes and its implications for the groundwater composition near the ash mound, Fuel 81 (2002) 1080-1090.

[11] K.C. Galbreath, C.J. Zygarlicke, Formation and chemical speciation of arsenic-, chromium-, and nickel-bearing coal combustion PM2.5, Fuel Processing Technology 85 (2004) 701-726.

[12] R. Świetlik, M. Trojanowska, M.A. Jóźwiak, Evaluation of the distribution of heavy metals and their chemical forms in ESP-fractions of fly ash, Fuel Processing Technology 95 (2012) 109-118.

[13] A. Baba, G. Gurdal, F. Sengunalp, Leaching characteristics of fly ash from fluidized bed combustion thermal power plant: case study: Çan (Çanakkale-Turkey), Fuel Processing Technology 91 (2010) 1073-1080.

[14] J.L. Ferna'ndez-Turiel, W. Carvalho, M. Cabanas, X. Querol, A. Lo'pez-Soler, Mobility of heavy metals from coal fly ash, Environmental Geology 23 (1994) 264-270.

[15] S. Bhattacharyya, R.J. Donahoe, D. Patel, Experimental study of chemical treatment of coal fly ash to reduce the mobility of priority trace elements, Fuel 88 (2009) 1173-1184.

[16] J. Jankowski, C.R. Ward, D. French, S. Groves, Mobility of trace elements from selected Australian fly ashes and its potential impact on aquatic ecosystems, Fuel 85 (2006) 243-256.

[17] A. Baba, A. Kaya, Leaching characteristics of solid wastes from thermal power plants of western Turkey and comparison of toxicity methodologies, Journal of Environmental Management 73 (2004) 199-207.

[18] S. Sushil, V.S. Batra, Analysis of fly ash heavy metal content and disposal in three thermal power plants in India, Fuel 85 (2006) 2676-2679.

[19] A. Ugurlu, Leaching characteristics of fly ash, Environmental Geology 46 (2004) 890-895.

[20] N. Saikia, S. Kato, T. Kojima, Compositions and leaching behaviors of combustion residues, Fuel 85 (2006) 264-271.

[21] B.M. Steenari, O. Lindqvist, Stabilization of bio fuel ashes for recycling to forest soil, Biomass and Bioenergy 13 (1997) 9-50.

[22] US Environmental Protection Agency, Method 1311-toxicity characteristic leaching procedure (TCLP), July, 1992. Washington, DC. 35pp. http://www.ehso. com/cssepa/TCLP_from\%20EHSOcom_Method_1311.pdf. [accessed 6th February 2012].

[23] American Society for Testing and Materials, D-3987-85, Standard test method for shake extraction of solid waste with water Annual Book of ASTM Standards, In: , 1995, pp. 14-17.

[24] D.J. Hassett, D.F. Pflughoeft-Hassett, L.V. Heebink, Leaching of CCBs: observations from over 25 years of research, Fuel 84 (2005) 1378-1383.

[25] ASTM C 204-11, Standard test methods for fineness of hydraulic cement by air-permeability apparatus, Pennsylvania, United States, 2005. 19428-2959. 
[26] M.J. Fishman, L.C. Friedman, Methods for determination of inorganic substances in water and fluvial sediments, Techniques of Water Resources Investigations of the United States Geological Survey, TWRI, Book 5, Chapter A1, Denver, 1989. p 545.

[27] G. Skodras, P. Grammelis, M. Prokopidou, E. Kakaras, G. Sakellaropoulos, Chemical, leaching and toxicity characteristics of CFB combustion residues, Fuel 88 (2009) 1201-1209.

[28] Y. Nathana, M. Dvoracheka, I. Pelly, U. Mimran, Characterization of coal fly ash from Israel, Fuel 78 (1999) 205-213.

[29] W.P. Linak, J.O.L. Wendt, Trace metal transformation mechanism during coal combustion, Fuel Processing Technology 39 (1994) 173-198.

[30] P.K. Mehta, Role of fly ash in sustainable development, forum on concentrate, fly ash, and the environmentavailable on, http://www.buildinggreen.com/features/ flyash/mehta.cfm1998last accessed 7th February 2012.

[31] O. Bayat, Characterisation of Turkish fly ashes, Fuel 77 (1998) 1059-1066.

[32] O. Dahl, R. Pöykiö, H. Nurmesniemi, Concentrations of heavy metals in fly ash from a coal-fired power plant with respect to the new Finnish limit values, J. Mater Cycles, Waste Management 10 (2008) 87-92.

[33] N. Koukouzas, C. Ketikidis, G. Itskos, Heavy metal characterization of CFB-derived coal fly ash, Fuel Processing Technology 92 (2011) 441-446.

[34] G. (Güler) Akar, E. Güler, U. Ipekoglu, A. Seyrankaya, H. Mordogan, Leachability of elements contained in coal ash samples from coal-fired power plants in western Turkey, In: 10th Int. Mineral Process. Symp, 2004, pp. 717-723.

[35] G. Akar, The determination of heavy metal contamination at the coal ash waste sites, Msc. Thesis. (2001).
[36] Y. Zhao, J. Zhang, C. Tian, H. Li, X. Shao, C. Zheng, Mineralogy and chemical composition of high-calcium fly ashes and density fractions from a coal-fired power plant in China, Energy \& Fuels 24 (2010) 834-843.

[37] D. Vamvuka, E. Kakaras, Ash properties and environmental impact of various biomass and coal fuels and their blends, Fuel Processing Technology 92 (2011) 570-581.

[38] C. Decision, 2003/33/EC of 19 December 2002 establishing criteria and procedures for the acceptance of waste at landfills pursuant to Article 16 of and Annex II to Directive 1999/31/EC, Official Journal of the European Union 11 (2003) 27-49.

[39] A.G. Kim, The effect of alkalinity of Class F PC fly ash on metal release, Fuel 85 (2006) 1403-1410.

[40] M. Zandi, N.V. Russell, Design of a leaching test framework for coal fly ash accounting for environmental conditions, Environmental Monitoring and Assessment 131 (2007) 509-526.

[41] M. Izquierdo, N. Moreno, O. Font, X. Querol, E. Alvarez, D. Antenucci, H. Nugteren, Y. Luna, C.F. Pereira, Influence of the co-firing on the leaching of trace pollutants from coal fly ash, Fuel 87 (2008) 1958-1966.

[42] R. Świetlik, M. Trojanowska, M.A. Jóźwiak, Evaluation of the distribution of heavy metals and their chemical forms in ESP-fractions of fly ash, Fuel Process Technology 95 (2012) 109-118. 